\title{
Influence of Pharmacy Characteristics and Customer Quality of Life on Satisfaction of Community Pharmacy Customers
}

\author{
Ali Azeez Al-Jumaili, MPH, PhD 1,2, Inaam Ahmed Ameen, PhD²; Doaa Asaad Alzubaidy, BS Pharm² \\ ${ }^{1}$ The University of lowa College of Pharmacy, USA; ${ }^{2}$ University of Baghdad College of Pharmacy, Baghdad, Iraq
}

\begin{abstract}
Objectives: The study objectives were to evaluate customer satisfaction with community pharmacy services and measure the relationships between customer satisfaction and pharmacy/pharmacist characteristics and customer quality of life.

Methods: This was a cross-sectional survey of a convenience sample of customers at 20 community pharmacies in 10 different geographical areas in Baghdad city between May and September 2018. We used the satisfaction items which were developed by Paterson and colleagues in 2013. The survey also assessed customer quality of life (QoL) with 12 QoL items.

Results: The study recruited 400 pharmacy customers. Overall, customers reported good satisfaction with community pharmacy services. The most three satisfying aspects were the professional appearance of the pharmacy, the professionalism of pharmacy staff and explanations of possible adverse medication effects. Three customer characteristics were associated with high satisfaction rates including male gender, buying medications without a prescription, and seeking services for themselves. Three pharmacy characteristics increased the customer satisfaction rate including the availability of female pharmacists, having more than one pharmacist, and whether the pharmacy is open full time. For quality of life, patients who had a limitation in their activities and those who accomplished less than they would like were less satisfied with pharmacy services.

Conclusions: To improve pharmacy services, pharmacists need to enhance their professional appearance, allocate more time for patient counselling, help patients to manage their medications and extend their working hours to meet customer needs.
\end{abstract}

Keywords: Community Pharmacy, Patient Satisfaction, Quality of Life

\section{Introduction}

Definitions of customer satisfaction are widely discussed by several researchers and organizations who increasingly desire to measure it. Dehghan and colleagues conceptualize satisfaction as based on the customer's experience of both contact with the organization and personal outcomes (1). According to this study, satisfaction can be experienced in a variety of situations and is connected to both goods and services. This definition views the "individual" as a powerful force in determining satisfaction levels (2). Many researchers conceptualize customer satisfaction as customers' feelings of pleasure or disappointment resulting from comparing a product's perceived performance (or outcome) in relation to their expectations (3). Customer satisfaction is a pleasurable fulfillment response while dissatisfaction is an unpleasable one (4). Satisfaction and dissatisfaction are two ends of a continuum, and the degree of satisfaction is defined by a comparison between expectations and outcome. Customers are satisfied if the outcome of the service meets expectations. When the service quality exceeds the expectations, the service provider would win a satisfied customer (1). Dissatisfaction occurs when the perceived overall service quality does not meet expectations. Sometimes customer's expectations are met, yet the customer is not satisfied. This occurs when expectations are low (4).

Corresponding author: Ali Azeez Al-Jumaili, MPH, PhD The University of lowa College of Pharmacy, USA University of Baghdad College of Pharmacy, Baghdad, Iraq Email: aliazeezali-aljumaili@uiowa.edu
In a retail pharmacy chain context, this implies that no two pharmacy employees will deliver the exact same standard of service to the customer. Also, no two customers will rate the standard of service of the same employee identically. Employee levels of service vary and the challenge for a service provider is to ensure that there are minimum service standards that all employees must adhere to. This can be achieved through training and development, providing incentives and conducting quality assurance (5).

Studies suggest that there is a positive relationship between service quality and the satisfaction of customers. Service quality is the impression customers have of the superiority and inferiority of the service provider (6). Chau and Kao state that service quality and its dimensions have a direct impact on customers' evaluation of a company and customer satisfaction (7).

Various researchers held different views of the relationship between dimensions of service quality and customer satisfaction. Cavana and Lo found that convenience and reliability do not have any significant relationship with customer satisfaction, while assurance, empathy and responsiveness have a strong relationship with customer satisfaction (8). Lai (2004) concludes a significant positive relationship between customer satisfaction and service quality dimensions of tangibles, empathy and assurance (9). Ahmed and colleagues indicate that there is no significant relationship between empathy and customer satisfaction, but service quality dimensions of assurance, reliability, tangibility and responsiveness have a positively significant relationship with 
satisfaction (10). Baumann and colleagues. found that the effectiveness of the service provider's attitude and empathy of staff leads to a higher degree of customer satisfaction (11). They further state that effective attitude has a long-term impact on customer satisfaction, while empathy has a shortterm relationship with satisfaction.

The implications of the research regarding the relationship between service quality and customer satisfaction are huge. In health services, healthcare providers need to ensure that patient perceptions of service quality are consistently higher than their expectations so that patients remain satisfied (12).

Quality of life (QoL) can be defined as person's own estimation of physical, psychological or social well-being (13). It is important to assess multidimensional characteristics of QoL such as physical (sign of illness and therapy), functional (ability to move and mobility), social (interpersonal contact and relationships) or psychological (mental health and stability) abilities (14). Quality of life (QoL) is not a constant value. The QoL can differ in one patient over time or depending on the situation. The QoL of two people suffering from the same diagnosis can be different. Various factors can contribute to QoL, such as culture, social environment, or the patients' expectations (14). The researcher's goal is to choose an instrument to measure QoL (15). Health related questionnaires, which are used for assessing QoL, can be divided in general health questionnaires and disease related questionnaires (16).

Previous studies in the literature either measured community pharmacy patients' satisfaction or patient quality of life while in this study, we evaluated both community pharmacy patient satisfaction and quality of life in addition to the relationship between these two domains. We focused on measuring community pharmacy customers satisfaction because it is closely related to patient clinical outcomes. The study objectives were to evaluate customer satisfaction with community pharmacy services and measure the relationships between customer satisfaction and pharmacy/pharmacist characteristics and customer quality of life.

\section{Methods}

This cross-sectional study included two surveys: one for pharmacy customers and second one for pharmacists. The first survey included a convenience sample of customers at 20 community (independent) pharmacies in 10 different geographical areas in Baghdad city. This number of pharmacies was chosen to ensure adequate representation of pharmacies across the city. A paper survey was administered between May and September 2018 to community pharmacy customers. The survey administration and collection were conducted by the same researcher (external pharmacist). The researcher asked customers aged 18 years or older whether they were willing to participate in this voluntary survey. After obtaining customer's consent, the researcher administered the survey to the participant. Given that there is not a private section for patients in most Iraqi community pharmacies, the participants filled the survey within pharmacy and asked the researcher for help when needed.

We used the pharmacy customer satisfaction items which were developed by Paterson and colleagues in 2013 (14). We translated the original survey items from English to Arabic and then conducted backward translation (Arabic to English) to validate the translation. The translation used formal methodology by Wild (2005)(15). We translated the survey items to Arabic since most Iraqi people have inadequate English skills. The customer survey included two parts. The first part was designed to assess customer satisfaction (21 questions), service awareness and demographics. The questions were rated using the five-point Likert-scale ranging from "poor" to "excellent". The second part of customer survey was designed to assess the customer quality of life with 12 items covering different life activities. These were translated to Arabic by two researchers who also back translated the items.

The researcher also asked the 20 community pharmacists (who were available on the visit day) to fill a survey. The survey asked about the characteristics of the participating pharmacists and pharmacies. The pharmacist/pharmacy survey items are in English because pharmacists understand English well.

The survey questions included binary (yes/no) answers, a twopoint scale, a four-point scale and a five-point scale. The two surveys were pre-tested with a small pilot study of pharmacy customers and the feedback was used to enhance the item translation.

The study was approved by the ethical and scientific committee at the University of Baghdad College of Pharmacy.

Statistical Analyses: The data were analyzed using Statistical Package for Social Sciences (SPSS) version 20. Descriptive statistics including frequency, percentage, mean and standard deviation were computed. Either t-test (if the variables were 2) or ANOVA (if the variables were more than 2) were used to compare different means. A P-value of $<0.05$ was used as a cutoff point for determining statistically significance. The independent $t$-test was used to assess gender differences and differences between those receiving dispensing-only services versus participants receiving other pharmacy services. The ANOVA was employed to compare the differences in age categories and educational levels with regard to satisfaction. Satisfaction was reported using 5-point scale where: $0=$ poor, 1 = fair, 2 = good, 3 = very good, and $4=$ excellent. Patient satisfaction level was rated as follows: point $\leq 3$ was considered as low satisfaction; while point greater than three was considered a high satisfaction. 


\section{Results}

The study recruited 20 pharmacists and 400 customers from 20 community pharmacies. The customers' age range was $18-78$ years (mean $42.9 \pm 6.5$ years). The sample was predominately female (two-third), and most of them had prescriptions (69.8\%) and sought services for themselves (68.3\%). According to their level of education, $32.3 \%, 46.8 \%$, and $21 \%$ of them had finished elementary school, secondary school and college respectively (Table 1).

Most participants rated their satisfaction with pharmacy services as good and very good. Thus, the overall satisfaction can be rated between these two limits. The most three satisfying aspects were the professional appearance of the pharmacy $(4.02 \pm 0.93)$, the professionalism of the pharmacy staff (3.84 \pm 0.9$)$ and how well the pharmacist explained possible adverse effects $(3.81 \pm 1.87)$. On the other hand, the least three satisfying aspects were the pharmacist's efforts to help patients to improve their health or stay healthy $(2.49 \pm 0.93)$, how well the pharmacist helped patients to manage their medications $(2.77 \pm 0.11)$, and the pharmacist's efforts to solve problems that patients had with their medications $(2.79 \pm 1.22)$ (Table 2).

The relationship between six customer characteristics and pharmacy satisfaction were measured (Table 1). Three of these characteristics were significantly associated with satisfaction. Men were significantly more satisfied with pharmacy services than women. Customers who had a prescription were significantly less satisfied than those bought medications without a prescription. Finally, patients who sought services for themselves were significantly more satisfied than customers who sought services for their relatives. On the other hand, the educational level and age of customers seems to have no association with satisfaction (Table 1).

The associations between pharmacy/pharmacist characteristics and customer satisfaction were also measured (Table 3). Among 14 studied characteristics, only four had significant influence on customer satisfaction. Customers were significantly more satisfied with female pharmacists than male (Table 3). A larger number of pharmacists in the pharmacy (more than one) was associated with more customer satisfaction. When the pharmacy had a low workload, customers reported significantly more satisfaction than pharmacy with moderate workload. Finally, pharmacies that were open for long business hours (full-time) had significantly higher satisfaction rate than those with shorter opening hours (evening only).

More than $80 \%$ of the participants had good QoL (Table 4). Table 4 shows the association between the QoL of customers and satisfaction with pharmacy services. Only two aspects of quality of life showed a significant association with satisfaction rates. Customers who had no limitation in activities were significantly more satisfied with pharmacy services than those who had some limitation. On the other hand, customers who felt calm and peaceful most of the time showed more satisfaction with pharmacy services than those who did not have such feelings.

\section{Discussion}

Customer satisfaction with pharmacy services has been related to improved patient outcomes. Thus, the evaluation of satisfaction rate will be helpful in identifying specific areas of pharmacy services which need improvement, and for promoting positive change in the community pharmacy services provided in Iraq. In the present study, the mean level of satisfaction was good because it falls above the moderate level in the five-point Likert scale (Table 1). This finding is comparable to other community pharmacy reports in some developed countries including Spain and Portugal (16) (17). Similarly, the results are consistent with a study conducted in Botswana which assessed customer satisfaction with pharmacy services as part of overall health services and reported a relatively high level of satisfaction (18) . On the other hand, satisfaction rates in Baghdad are much higher than those reported in Ethiopia and Nigeria, in which similar community pharmacy studies were conducted (5)(19). We can conclude that pharmacy services in Baghdad are well organized and professional because customer/patient satisfaction is consistent with that in developed countries, while it's higher than that in less developed countries. Community pharmacists not only dispense medications, but also educate and counsel patients about their diseases and medications.

However, patient satisfaction does not only depend on the quality of service provided by the pharmacy, but also on the patient expectations for this service. When patient expectations are high (for example the availability of all needed drugs, full cooperation of pharmacy staff, and comfortable waiting room), satisfaction will be low if any of these circumstances are missing. In contrast, when patient expectations are moderate, satisfaction will be high when customers find services above their expectations. Thus, it is reasonable to assume that most enrolled pharmacies in this study provided services at or above the expectation level of their customers.

The three highest satisfaction scores in the current study were the professional appearance of the pharmacy $(4.02 \pm 0.93)$, the professionalism of the pharmacy staff $(3.84 \pm 0.9)$ and how well the pharmacist explained possible adverse effects (3.81 1.87 ). In a similar study conducted in the USA, Patterson and colleagues. investigated the satisfaction of a random sample of 500 patients with community pharmacy services (14). The three highest satisfaction scores in the American study included the availability of pharmacists to answer patient questions, the courtesy and respect shown by pharmacy staff, and the professionalism of pharmacy staff. Several factors determine the attitude of patients towards different aspects of pharmacy services. Among these are traditions, religions and educational levels. For example, "the professional appearance of 
pharmacy" may not be considered an important factor for patients in a country like the USA, but it is very important in Iraq.

In another study, Franic and colleagues surveyed 175 patients to determine the most important factors that influence pharmacy selection (20). Costumers were asked to list three to five features that they considered relevant to the pharmacy selection process. Surprisingly, the results were very similar to the current study. It was not the pharmacy products which determined consumer choice. Rather, personal characteristics such as professionalism, friendliness, and caring are the drivers to select certain pharmacies.

On the other extreme and most importantly, the three lowest scores for satisfaction in our study were the pharmacist efforts to help improve patient health $(2.49 \pm 0.93)$, how well the pharmacist helped patients to manage medications (2.77士 0.11 ), and the pharmacist's efforts to solve patient medication problems (2.79 \pm 1.22$)$. All three aspects are related to pharmacist behavior. This may be due to a general belief among Iraqi patients that the doctor, but not the pharmacist, is the professional and the main source of information about health, medications, and medication problems. Additionally, Iraqi community pharmacies are not equipped with electronic systems that can help pharmacists to detect potential medication-problems, manage patient medications and followup patient adherence. In contrast, a study in Turkey (21) and another in the U.S. (22) found that electronic systems can help pharmacists to improve patient health and medication safety. Retrieving the results of the American study, the lowest satisfaction scores were the privacy of conversations with a pharmacist, the pharmacist's interest in patient health and the pharmacist's efforts to help improve health (14). Therefore, to improve pharmacy services, pharmacists need to address these three points of dissatisfaction in addition to increasing patient awareness that these are more closely associated with pharmacists than doctors.

The current study revealed that three characteristics of customers/patients were significantly associated with satisfaction (Table 1$)$. Men were significantly ( $P$-value $<0.05$ ) more satisfied with pharmacy services than women. Customers who had prescriptions were less satisfied than those were buying medications without prescription. Finally, customers who sought services for themselves were more satisfied than customers who sought services for their relatives. Similar results regarding gender were reported in a cross-sectional Brazilian study of more than 4000 patients which found that men were more satisfied than women (23). This may be attributed to the fact that women are more critical of all types of services including pharmacy service (24). However, the same Brazilian study showed that older patients were more satisfied than younger patients (23). This result was not found in present study. The author explained this finding by suggesting that older people have lower expectations than younger people in relation to pharmacy services. In a Portuguese study, the highest satisfaction rate was found among customers with a university degree compared to those of lower educational levels (16).

The high satisfaction rates among customers who purchased medications without a prescription and those who sought services for themselves may be attributed mainly to psychological reasons. Those who purchased prescription only medications (POMs) without a prescription were satisfied because they did not have to visit the doctor. For example, a previous Iraqi study reported that community pharmacy patients can obtain antibiotics without prescription (25). On the other hand, those who purchased medications for others usually complained about the pharmacy service when it was good because they had to wait for pharmacist to prepare and dispense the medications

The present study revealed four pharmacy/pharmacist characteristics that significantly influence customer satisfaction (Table 3). Patients were more satisfied with female pharmacists, with availability of more than one pharmacist, with low workload in pharmacy, and with pharmacies that had full-time opening hours (open morning and evening).

The other three satisfying characteristics including the availability and convenience of the provided service. It is reasonable for patients to be satisfied when they can get medications any time during the day without waiting. Furthermore, such characteristics enable patients to be consulted about their medications which increases their satisfaction about the services. A recent cross-sectional study to assess the satisfaction of 507 Spanish patients with pharmacy services reported that time devoted and information provided by pharmacists to patients are the most critical factors which determine patient satisfaction (26).

This study also looked at the association between patient satisfaction and their quality of life (QoL). Two aspects of QoL showed significant associations with satisfaction. Patients who had no activity limitations were more satisfied than those who had a limitation, and patients who accomplished what they would like were more satisfied than those who accomplished less than they would like. Similarly, an Iraqi study concludes that patients with chronic diseases (diabetes and hypertension) have lower quality of life compared to healthy individuals (27). These results can be explained from two points of view: psychological and physical. Psychologically, patients who are not limited as those accomplish what they would like are usually feel better and may be more satisfied with a wide range of public and private services including pharmacy services. Physically, patients without limited activities are less affected than their counterparts because they can experience most life activities. 


\section{Limitations}

The study had some limitations including the small sample size of the participants. Moreover, this study was conducted in one governorate. Hence, the finding might not be possible to be generalized to the whole country. However, it covered 20 different pharmacies in 10 different geographical areas. Finally, the study used a convenience sample because almost all healthcare settings including community pharmacies have not implemented electronic health records (28).

\section{Conclusions}

There was an overall good satisfaction of patients with community pharmacy services. Customers were most satisfied with the professional appearance of the pharmacy, the professionalism of pharmacy staff and explanation of possible adverse medication effects. Customers were least satisfied with the pharmacist's efforts to improve patient health, manage the patient medications, and address medication-related problems. Three customer characteristics were associated with high satisfaction rates including male gender, buying medications without a prescription, and seeking services for themselves. Three pharmacy/pharmacist characteristics which increase customer satisfaction rates are the availability of a female pharmacist, having more than one pharmacist, and full-time opening hours. For quality of life, patients who have a limitation in their activities and those who accomplish less than they would like are less satisfied with pharmacy services. To improve community pharmacy services, community pharmacists need to enhance professional appearance, allocate more time for patient counselling, and increase their efforts to help patients managing their medications. Community pharmacies should have enough staff number particularly female pharmacists and extend their working hours to meet costumers' needs.

\section{References}

1. Dehghan A, Zenouzi B, Albadvi A. An Investigation on the Relationship between Service Quality and Customer Satisfaction: In the Case of CCG CO. Int Bus Res. 2011;5(1):3-8.

2. Cengiz E. Measuring Customer Satisfaction: Must or Not? J Nav Sci Eng. 2010;6(2):76-88.

3. Philip Kotler K keller. Marketing Management. New Jersey: Prentice-Hall; 2006.

4. Buttle F. Customer Relationship Management: Concepts and Tools [Internet]. 2nd Editio. Journal of Chemical Information and Modeling. Oxford: Elsevier Butterworth-Heinemann; 2009. Available from: https://knowledgestreams.files.wordpress.com/2013 /07/francis_buttle-

customer_relationship_management_second_edition -butterworth-heinemann2008_2.pdf
5. Surur AS, Teni FS, Girmay G, Moges E, Tesfa M, Abraha M. Satisfaction of clients with the services of an outpatient pharmacy at a university hospital in northwestern Ethiopia: A cross-sectional study Health systems and services in low and middle income settings. BMC Health Serv Res [Internet]. 2015;15(1). Available from: http://dx.doi.org/10.1186/s12913015-0900-6

6. Evangelos Tsoukatos and Graham K. Rand. Path analysis of perceived service quality, satisfaction and loyalty in Greek insurance. Manag Serv Qual. 2006;16(5):501-5019.

7. Chau VS KY. Bridge over troubled water or long and winding road? Gap-5 in airline service quality performance measures. Manag Serv Qual. 2009;19(1):106-34.

8. Cavana RY, Corbett LM LY. Developing zones of tolerance for managing passenger rail services quality. Int J Qual Manag. 2007;24(1):7-31.

9. Lai TL. Service quality and perceived value's impact on satisfaction, intention and usage of short message service (SMS). Inf Syst Front. 2004;6(4):353-68.

10. Ahmed I, Musarrat Nawaz M, Usman A, Shaukat MZ, Ahmad N, Iqbal H. Impact of Service Quality on Customers Satisfaction: Empirical evidence from telecom sector of Pakistan. Interdiscip J Contemp Res Bus [Internet]. 2010;98-113. Available from: http://joc.hcc.edu.pk/faculty_publications/April10_IJ CRB.pdf

11. Baumann C, Burton S, Elliott G, Kehr HM. Prediction of attitude and behavioural intentions in retail banking. Int J Bank Mark. 2007;25(2):102-16.

12. Nadi A, Shojaee J, Abedi G, Siamian H, Abedini E, Rostami F. Patients' Expectations and Perceptions of Service Quality in the Selected Hospitals. Med Arch (Sarajevo, Bosnia Herzegovina). 2016;70(2):135-9.

13. Quaranta L, Riva I, Gerardi C, Oddone F, Floriano I, Konstas AGP. Quality of Life in Glaucoma: A Review of the Literature. Adv Ther. 2016;33(6):959-81.

14. Brandon J. Patterson, William R. Doucette, Julie M. Urmie and RPM. Exploring Relationships among Pharmacy Service Utilization, Patronage Motives, and Patient Satisfaction in a Service-Oriented Pharmacy. J Am Pharm Assoc [Internet]. 2013;53(4):382-9. Available from: https://www.researchgate.net/publication/25333480 4_Exploring_relationships_among_pharmacy_service _use_patronage_motives_and_patient_satisfaction 
15. Wild D, Grove A, Martin M, Eremenco S, McElroy S, Verjee-Lorenz A, et al. Principles of good practice for the translation and cultural adaptation process for patient-reported outcomes (PRO) measures: Report of the ISPOR Task Force for Translation and Cultural Adaptation. Value Heal [Internet]. 2005;8(2):94-104. Available from: http://dx.doi.org/10.1111/j.15244733.2005.04054.x

16. Pinto AR, Machado A, Gonçalves E, Salsas L, Vicente $\mathrm{T}$, Ribeiro $\mathrm{MI}$, et al. Users satisfaction regarding the service provided in community pharmacies. Adv Pharmacol Pharm. 2014;2(2):18-29.

17. Marquez-Peiro JF P-PC. Evaluation of patient satisfaction in outpatient pharmacy. Farm Hosp. 2008;32(2):71-6.

18. Bamidele AR, Hoque ME, van der Heever H. Patient satisfaction with the quality of care in a primary health care setting in Botswana. South African Fam Pract. 2011;53(2):170-5.

19. Offor I, Enato EFO. Patients' assessment of pharmacists' medication counseling in a psychiatric hospital in Nigeria. Trop J Pharm Res.

2011;10(4):507-16.

20. Franic DM, Haddock SM, Tucker LT WN. Pharmacy patronage: identifying key factors in the decision making process using the determinant attribute approach. J Am Pharm Assoc. 2008;48(1):71-85.

21. Sancar M, Kaşik A, Okuyan B, Batuhan S, İzzettin FV. Determination of potential drug-drug interactions using various software programs in a community pharmacy setting. Turkish J Pharm Sci. 2019;16(1):149.

22. Stanton-Robinson C, Al-Jumaili AA, Jackson A, Catney C, Veach S, Witry MJ. Evaluation of community pharmacist-provided telephone interventions to improve adherence to hypertension and diabetes medications. J Am Pharm Assoc. 2018;58(4).
23. Soeiro OM, Tavares NUL, Júnior JM do N, Junior AAG, Costa EA, Acurcio F de A, et al. Patient satisfaction with pharmaceutical services in Brazilian primary health care. Rev Saude Publica. 2017;51:1s-11s.

24. Vinterflod C, Gustafsson M, Mattsson S, Gallego G. Physicians' perspectives on clinical pharmacy services in Northern Sweden: A qualitative study. BMC Health Serv Res. 2018;18(1).

25. Al-Jumaili AA, Hussein AH, Al-Rekabi MD, Raheem SA, Ernst EJ. Antimicrobial utilization in an Iraqi province: a comprehensive evaluation of antibiotic source and cost. Int J Pharm Pract. 2017;25(1).

26. Martínez-López-de-Castro N, Álvarez-Payero M, Martín-Vila A, Samartín-Ucha M, Iglesias-Neiro $P$, Gayoso-Rey M, et al. Factors associated with patient satisfaction in an outpatient hospital pharmacy. Eur J Hosp Pharm . 2017;183-8.

27. Al-ibrahimy AS, Al-tukmagi HF. Assessing Quality of Life Among Patients with Diabetes Mellitus, Hypertension or Both Diseases in Al-Najaf Province / Iraq. Iraqi J Pharm Sci [Internet]. 2017;26(2):29-40. Available from: https://www.researchgate.net/publication/33020193 3_Assessing_Quality_of_Life_among_Patients_with_ Diabetes_Mellitus_Hypertension_or_Both_Diseases_i n_Al-Najaf_Province_Iraq

28. Al-Jumaili AAA, Jabri AM, Al-Rekabi MD, Abbood SK, Hussein AH. Physician Acceptance of Pharmacist Recommendations about Medication Prescribing Errors in Iraqi Hospitals. Inov Pharm. 2016;7(3). 
Table 1: Customer characteristics and their association with satisfaction

\begin{tabular}{|c|c|c|c|}
\hline Characteristic & $\mathbf{N}(\%)$ & Mean $\pm S D$ of satisfaction & P-Value \\
\hline $\begin{array}{l}\text { Age, years (mean } \pm S D \text { ) } \\
18-35 \\
36-55 \\
56-78\end{array}$ & & $\begin{array}{l}42.9 \pm 6.5 \\
3.3 \pm 0.9 \\
3.2 \pm 1.1 \\
3.4 \pm 1.1\end{array}$ & 0.281 \\
\hline $\begin{array}{l}\text { Gender, No (\%) } \\
\text { Male } \\
\text { Female }\end{array}$ & $\begin{array}{l}158(39.5) \\
242(60.5)\end{array}$ & $\begin{array}{l}3.8 \pm 1.0 \\
3.3 \pm 0.9\end{array}$ & $0.042 *$ \\
\hline $\begin{array}{l}\text { With a prescription } \\
\text { Yes } \\
\text { No }\end{array}$ & $\begin{array}{l}279(69.8) \\
121(30.3)\end{array}$ & $\begin{array}{l}3.2 \pm 1.1 \\
3.7 \pm 1.2\end{array}$ & $0.044^{*}$ \\
\hline $\begin{array}{l}\text { Return to doctors for review } \\
\text { Yes } \\
\text { No }\end{array}$ & $\begin{array}{l}218(54.5) \\
182(45.5)\end{array}$ & $\begin{array}{l}3.5 \pm 1.1 \\
3.0 \pm 0.9\end{array}$ & 0.074 \\
\hline $\begin{array}{l}\text { Service sought for } \\
\text { Self } \\
\text { Others (family/relative) }\end{array}$ & $\begin{array}{l}273(68.3) \\
127(31.8)\end{array}$ & $\begin{array}{l}3.8 \pm 1.1 \\
3.2 \pm 1.0\end{array}$ & $0.037^{*}$ \\
\hline $\begin{array}{l}\text { Educational status } \\
\text { Primary school } \\
\text { Secondary school } \\
\text { College degree or higher }\end{array}$ & $\begin{array}{l}129(32.3) \\
187(46.8) \\
84(21.0)\end{array}$ & $\begin{array}{l}3.2 \pm 1.0 \\
3.4 \pm 1.2 \\
3.2 \pm 1.7\end{array}$ & 0.487 \\
\hline
\end{tabular}

*Significant (P-value< 0.05), (Student t-test for two mean comparisons, and ANOVA test for more than two mean comparisons) 
Table 2: Overall pharmacy customer's satisfaction

\begin{tabular}{|c|c|c|c|c|c|c|}
\hline Question & $\begin{array}{l}\text { Poor } \\
(\%)\end{array}$ & $\begin{array}{l}\text { Fair } \\
\text { (\%) }\end{array}$ & $\begin{array}{l}\text { Good } \\
(\%)\end{array}$ & $\begin{array}{l}\text { Very good } \\
\qquad(\%)\end{array}$ & $\begin{array}{l}\text { Excellent } \\
\qquad(\%)\end{array}$ & Mean \pm SD \\
\hline Your overall pharmacy services are & 2.8 & 17.7 & 46.0 & 18.8 & 14.8 & $3.4 \pm 1.0$ \\
\hline $\begin{array}{l}\text { The availability of the pharmacist to answer your } \\
\text { questions is }\end{array}$ & 2.3 & 17.0 & 43.5 & 17 & 20.3 & $3.7 \pm 1.0$ \\
\hline $\begin{array}{l}\text { The courtesy and respect shown you by the } \\
\text { pharmacy staff is: }\end{array}$ & 3.3 & 12.0 & 41.5 & 29.5 & 13.8 & $3.4 \pm 0.9$ \\
\hline The professionalism of the pharmacy staff & 2.0 & 14.3 & 44.3 & 32 & 7.5 & $3.8 \pm 0.9$ \\
\hline $\begin{array}{l}\text { If you ordered your prescription in advance (by } \\
\text { phone or email), the speed for which it was ready } \\
\text { for pick up is: }\end{array}$ & 1.5 & 15.3 & 45.8 & 22.8 & 14.8 & $3.3 \pm 0.8$ \\
\hline $\begin{array}{l}\text { How well the pharmacist answers your } \\
\text { questions? }\end{array}$ & 2.0 & 18.5 & 47.8 & 17.5 & 14.3 & $3.3 \pm 0.9$ \\
\hline $\begin{array}{l}\text { The pharmacist's ability to advise you about } \\
\text { problems that you might have with your } \\
\text { medications is: }\end{array}$ & 3.0 & 12.0 & 41.0 & 18.3 & 25.8 & $3.5 \pm 1.0$ \\
\hline $\begin{array}{l}\text { How well the pharmacist explains what your } \\
\text { medications do is: }\end{array}$ & 3.5 & 10.8 & 36.5 & 33 & 11.3 & $3.2 \pm 1.0$ \\
\hline The promptness of prescription drug service is: & 2.5 & 18 & 37.0 & 29.5 & 13 & $3.2 \pm 1.0$ \\
\hline $\begin{array}{l}\text { The pharmacist's professional relationship with } \\
\text { you is: }\end{array}$ & 2.5 & 29 & 47.0 & 10.3 & 12.2 & $3.0 \pm 0.9$ \\
\hline $\begin{array}{l}\text { How well the pharmacist instructs you about how } \\
\text { to take your medications is }\end{array}$ & 3.3 & 20.8 & 44.8 & 22.8 & 7.5 & $3.1 \pm 0.9$ \\
\hline $\begin{array}{l}\text { The pharmacist's efforts to solve problems that } \\
\text { you have with your medications are: }\end{array}$ & 12.0 & 31.0 & 24.3 & 11.0 & 11.7 & $2.8 \pm 1.2$ \\
\hline $\begin{array}{l}\text { The responsibility that the pharmacist assumes } \\
\text { for your drug therapy is: }\end{array}$ & 2 & 28 & 36.5 & 17.8 & 15.8 & $3.1 \pm 1.0$ \\
\hline $\begin{array}{l}\text { The amount of time the pharmacist offers to } \\
\text { spend with you is: }\end{array}$ & 2.8 & 31.8 & 38 & 12.3 & 25.3 & $3.0 \pm 1.0$ \\
\hline $\begin{array}{l}\text { The pharmacist's efforts to ensure that your } \\
\text { medications do what they are supposed to are }\end{array}$ & 8.8 & 33 & 30.3 & 15.5 & 12.5 & $3.3 \pm 1.1$ \\
\hline $\begin{array}{l}\text { How well the pharmacist explains possible } \\
\text { adverse effects is }\end{array}$ & 7.0 & 37 & 29.5 & 17.3 & 9.5 & $3.8 \pm 1.1$ \\
\hline $\begin{array}{l}\text { How well the pharmacist helps you to manage } \\
\text { your medications? }\end{array}$ & 9.8 & 29.0 & 23.5 & 20.5 & 17.3 & $2.8 \pm 0.1$ \\
\hline The professional appearance of the pharmacy is & 0.75 & 7.3 & 20.3 & 25.5 & 61.7 & $4.0 \pm 0.9$ \\
\hline $\begin{array}{l}\text { The privacy of your conversations with the } \\
\text { pharmacist is }\end{array}$ & 4.0 & 13.0 & 44.0 & 29.5 & 9.5 & $2.9 \pm 0.9$ \\
\hline The pharmacist's interest in your health is & 21.0 & 26.5 & 24.5 & 15.8 & 12.3 & $2.9 \pm 0.9$ \\
\hline $\begin{array}{l}\text { The pharmacist's efforts to help you improve } \\
\text { your health or stay healthy are: }\end{array}$ & 23.5 & 30.8 & 21.8 & 17.5 & 6.5 & $2.5 \pm 0.9$ \\
\hline
\end{tabular}

Means reported using 5-point scale where: 0 = poor, $1=$ fair, $2=$ good, $3=$ very good, and $4=$ excellent. 
Table 3: Pharmacy/Pharmacist Characteristics and their association with customer's satisfaction

\begin{tabular}{|c|c|c|c|}
\hline Variables & $\begin{array}{c}\text { Frequency } \\
(\%)\end{array}$ & $\begin{array}{c}\text { Mean } \\
\text { satisfaction }\end{array}$ & $\begin{array}{c}\text { P- } \\
\text { value }\end{array}$ \\
\hline $\begin{array}{l}\text { Pharmacy surface area, } \mathrm{m}^{2} \\
\geq 40 \\
<40\end{array}$ & $\begin{array}{l}13(65) \\
7.0(35)\end{array}$ & $\begin{array}{l}3.4 \pm 1.0 \\
3.5 \pm 1.0\end{array}$ & 0.467 \\
\hline $\begin{array}{l}\text { Pharmacist experience, years } \\
\geq 10 \\
<10\end{array}$ & $\begin{array}{l}11(55) \\
9.0(45)\end{array}$ & $\begin{array}{l}3.6 \pm 1.0 \\
3.5 \pm 1.0\end{array}$ & 0.922 \\
\hline $\begin{array}{l}\text { Pharmacist gender } \\
\text { Male } \\
\text { Female }\end{array}$ & $\begin{array}{l}11(55) \\
9.0(45)\end{array}$ & $\begin{array}{l}3.0 \pm 0.8 \\
4.1 \pm 0.9\end{array}$ & $0.026^{*}$ \\
\hline $\begin{array}{l}\text { Number of pharmacists in the pharmacy } \\
\text { One } \\
\text { Two } \\
\text { Three }\end{array}$ & $\begin{array}{l}4.0(20) \\
4.0(20) \\
12(60)\end{array}$ & $\begin{array}{l}3.1 \pm 1.1 \\
3.4 \pm 1.1 \\
3.9 \pm 0.9\end{array}$ & $0.038 *$ \\
\hline $\begin{array}{l}\text { Number of pharmacy employees other than the pharmacist } \\
0-1 \\
2-4\end{array}$ & $\begin{array}{l}12(60) \\
8.0(40)\end{array}$ & $\begin{array}{l}3.4 \pm 0.9 \\
3.9 \pm 0.9\end{array}$ & 0.217 \\
\hline $\begin{array}{l}\text { Pharmacy workload } \\
\text { Low } \\
\text { Medium }\end{array}$ & $\begin{array}{l}3.0(15) \\
17(85)\end{array}$ & $\begin{array}{l}4.0 \pm 1.1 \\
3.1 \pm 0.9\end{array}$ & $0.037^{*}$ \\
\hline $\begin{array}{l}\text { Number of nearby physician clinics within } 100 \mathrm{~m} \\
0-3 \\
4-8\end{array}$ & $\begin{array}{l}11(55) \\
9.0(45)\end{array}$ & $\begin{array}{l}3.6 \pm 0.9 \\
3.7 \pm 1.0\end{array}$ & 0.850 \\
\hline $\begin{array}{l}\text { The pharmacy contains chair in waiting area for costumer } \\
\text { Yes } \\
\text { No }\end{array}$ & $\begin{array}{c}15(75) \\
5.0(25)\end{array}$ & $\begin{array}{l}3.8 \pm 0.9 \\
3.7 \pm 1.1\end{array}$ & 0.084 \\
\hline $\begin{array}{l}\text { The pharmacy measures blood pressure } \\
\text { Yes } \\
\text { No }\end{array}$ & $\begin{array}{l}5.0(25) \\
15(75)\end{array}$ & $\begin{array}{l}3.6 \pm 1.1 \\
3.3 \pm 1.0\end{array}$ & 0.612 \\
\hline $\begin{array}{l}\text { Price of pharmacy selling prescription is relatively } \\
\text { Inexpensive } \\
\text { Moderate }\end{array}$ & $\begin{array}{l}3.0(15) \\
17(85)\end{array}$ & $\begin{array}{l}3.7 \pm 1.3 \\
3.4 \pm 0.9\end{array}$ & 0.339 \\
\hline $\begin{array}{l}\text { The pharmacy income depends on } \\
\text { By hand } \\
\text { Prescription } \\
\text { Both }\end{array}$ & $\begin{array}{l}5.0(25) \\
4.0(20) \\
11(55)\end{array}$ & $\begin{array}{l}3.5 \pm 1.1 \\
3.2 \pm 1.0 \\
3.8 \pm 0.9\end{array}$ & 0.706 \\
\hline $\begin{array}{l}\text { The pharmacy monthly income is considered } \\
\text { Low } \\
\text { Fair } \\
\text { Good }\end{array}$ & $\begin{array}{l}3.0(15) \\
13(65) \\
4.0(20)\end{array}$ & $\begin{array}{l}3.5 \pm 1.2 \\
3.6 \pm 0.9 \\
3.7 \pm 1.0\end{array}$ & 0.451 \\
\hline $\begin{array}{l}\text { The pharmacy works full or part time } \\
\text { Full time } \\
\text { Part time }\end{array}$ & $\begin{array}{l}4.0(20) \\
16(80)\end{array}$ & $\begin{array}{l}4.0 \pm 1.4 \\
3.0 \pm 1.2\end{array}$ & $0.047^{*}$ \\
\hline $\begin{array}{l}\text { The pharmacist assistance helps to educate patients } \\
\text { Yes } \\
\text { No }\end{array}$ & $\begin{array}{l}12(60) \\
8.0(40)\end{array}$ & $\begin{array}{l}3.9 \pm 1.0 \\
3.4 \pm 1.0\end{array}$ & 0.162 \\
\hline
\end{tabular}

*Significant (P-value< 0.05), Student t-test for two mean comparisons, and ANOVA test for more than two mean comparisons. 
Table 4: Quality of life and customer satisfaction with pharmacy services

\begin{tabular}{|c|c|c|c|}
\hline Variables & $\begin{array}{l}\text { Frequency } \\
\text { (\%) }\end{array}$ & Mean satisfaction & P-value \\
\hline $\begin{array}{l}\text { Moderate activities } \\
\text { Limited a lot } \\
\text { Limited a little }\end{array}$ & $\begin{array}{l}16(4.0) \\
384(96)\end{array}$ & $\begin{array}{l}3.4 \pm 0.9 \\
3.4 \pm 0.9\end{array}$ & 0.911 \\
\hline $\begin{array}{l}\text { Climbing several flights of stairs } \\
\text { Limited a lot } \\
\text { Limited a little }\end{array}$ & $\begin{array}{c}19(4.8) \\
339(84.8)\end{array}$ & $\begin{array}{l}3.2 \pm 0.9 \\
3.4 \pm 1.1\end{array}$ & 0.189 \\
\hline $\begin{array}{l}\text { Accomplish less than you would like } \\
\text { Yes } \\
\text { No }\end{array}$ & $\begin{array}{c}48(12) \\
352(88)\end{array}$ & $\begin{array}{l}3.3 \pm 0.8 \\
3.8 \pm 0.8\end{array}$ & 0.056 \\
\hline $\begin{array}{l}\text { Limited in the kind of activities } \\
\text { Yes } \\
\text { No }\end{array}$ & $\begin{array}{c}46(11.5) \\
354(88.5)\end{array}$ & $\begin{array}{l}3.2 \pm 0.9 \\
3.6 \pm 0.9\end{array}$ & $0.042^{*}$ \\
\hline $\begin{array}{l}\text { Pain interferes with normal work } \\
\text { Extremely } \\
\text { Quite a bit } \\
\text { Moderately } \\
\text { A little bit }\end{array}$ & $\begin{array}{l}17(4.3) \\
36(9.0) \\
19(4.8) \\
328(82)\end{array}$ & $\begin{array}{l}3.1 \pm 1.0 \\
3.1 \pm 0.9 \\
3.3 \pm 0.8 \\
3.6 \pm 0.9\end{array}$ & 0.121 \\
\hline $\begin{array}{l}\text { In general, would you say your health is } \\
\text { Poor } \\
\text { Fair } \\
\text { Good } \\
\text { Very good }\end{array}$ & $\begin{array}{c}2.0(0.5) \\
28(7.0) \\
44(11) \\
326(81.5)\end{array}$ & $\begin{array}{l}3.1 \pm 0.9 \\
3.4 \pm 0.9 \\
3.3 \pm 0.8 \\
3.5 \pm 0.9\end{array}$ & 0.439 \\
\hline $\begin{array}{l}\text { Have a lot of energy } \\
\text { None of the time } \\
\text { A little of the time } \\
\text { Some of the time } \\
\text { A good bit of the time } \\
\text { Most of the time }\end{array}$ & $\begin{array}{c}3.0(0.8) \\
12(3.0) \\
45(11.3) \\
10(2.5) \\
330(82.5)\end{array}$ & $\begin{array}{l}3.3 \pm 1.2 \\
3.1 \pm 0.9 \\
3.7 \pm 0.9 \\
3.6 \pm 0.9 \\
3.6 \pm 0.9\end{array}$ & 0.311 \\
\hline $\begin{array}{l}\text { Felt calm and peaceful } \\
\text { None of the time } \\
\text { A little of the time } \\
\text { Some of the time } \\
\text { A good bit of the time } \\
\text { Most of the time }\end{array}$ & $\begin{array}{c}5.0(1.3) \\
17(4.3) \\
34(8.5) \\
10(2.5) \\
334(83.5)\end{array}$ & $\begin{array}{l}2.9 \pm 0.7 \\
3.1 \pm 0.8 \\
3.6 \pm 0.9 \\
3.3 \pm 0.8 \\
3.9 \pm 1.0\end{array}$ & $0.037 *$ \\
\hline $\begin{array}{l}\text { Felt downhearted and blue } \\
\text { All of the time } \\
\text { Most of the time } \\
\text { A good bit of the time } \\
\text { Some of the time } \\
\text { A little of the time }\end{array}$ & $\begin{array}{c}2.0(0.5) \\
16(4.0) \\
7.0(1.8) \\
37(9.3) \\
338(84.5)\end{array}$ & $\begin{array}{l}3.5 \pm 0.8 \\
3.3 \pm 0.9 \\
3.6 \pm 1.1 \\
3.4 \pm 1.0 \\
3.2 \pm 0.9\end{array}$ & 0.321 \\
\hline $\begin{array}{l}\text { Health interferes with social activities } \\
\text { All the time } \\
\text { Most of the time } \\
\text { Some of the time } \\
\text { A little of the time }\end{array}$ & $\begin{array}{c}11(2.8) \\
26(6.5) \\
14(3.5) \\
389(97.3)\end{array}$ & $\begin{array}{l}3.3 \pm 0.9 \\
3.2 \pm 0.9 \\
3.7 \pm 1.0 \\
3.3 \pm 0.9\end{array}$ & 0.098 \\
\hline $\begin{array}{l}\text { Accomplish less than you would like } \\
\text { Yes } \\
\text { No }\end{array}$ & $\begin{array}{c}48(12) \\
352(88)\end{array}$ & $\begin{array}{l}3.3 \pm 0.8 \\
3.8 \pm 0.8\end{array}$ & 0.056 \\
\hline $\begin{array}{l}\text { Didn't do activities as carefully as usual } \\
\text { Yes } \\
\text { No }\end{array}$ & $\begin{array}{c}44(11) \\
356(89)\end{array}$ & $\begin{array}{l}3.4 \pm 1.0 \\
3.7 \pm 0.9\end{array}$ & 0.219 \\
\hline
\end{tabular}

*Significant (P-value< 0.05), (Student t-test for two group comparisons, and ANOVA with post-hoc test for more than two category comparisons). 